\title{
In-depth analysis on the Methodology of Mufassirun and Muhaddithun
}

\author{
Adam Yusuf Adam ${ }^{1 *}$, Zayyanu Altine ${ }^{2}$ \\ ${ }^{1}$ Faculty of Arts and Islamic Studies, Department of Islamic Studies, Usmanu Danfodiyo University, Sokoto, Nigeria \\ 2Postgraduate Student, Faculty of Arts and Islamic Studies, Department of Islamic Studies, Usmanu Danfodiyo University, Sokoto, \\ Nigeria
}

\section{*Corresponding Author}

Adam Yusuf Adam

\section{Article History}

Received: 08.07.2019

Accepted: 20.07.2019

Published: 30.07 .2019

\begin{abstract}
Research generally implies diligent and systematic enquiry to discover or refine facts of knowledge in any particular field of endeavor. The essence of research in any field is to extend knowledge, and to cope with the demand of the area, a valid approach has to be developed by experts and specialists of the domain. Therefore, this paper examines the method used by the Quran's interpreters that is Mufassirun which they used in their Tafasir and it can be used in any Islamic-related research nowadays. Also this paper explains the standered method used by Muhaddithun in the Sanad and Matan of the Hadith when analyzing its authenticity or quality. The method used when conducting this research is analytical method.
\end{abstract}

Keywords: In-depth analysis, Methodology, Mufassirun, Muhaddithun, Hadith, Sanad and Matan

\section{INTRODUCTION}

Research is conducted to find the answer to the "uncertainties", researchers conducted their research because they are uncertain of a specific matter or phenomena that either had happened, is happening or did not happen yet. Research is a systematic process that involves research methodology, data collection, data analysis and report the information obtained in systematic ways.

The main steps consist in common research methodology also included in discipline of classic Islamic study. A wellorganized research methodology had been used by previous Islamic scholars in conducting a study regarding a certain matter. However, both work differently in their own ways. For example, research methodology used by figh scholar maybe different from the method used by the scholars of kalam (tauhid), hadith and interpretation. All of these depend on the research objective that needs to be attained. Nonetheless, the methods used by the Islamic scholars in the past were not really systematized and examined thoroughly to ensure that it is still relevant to be used in the following phase according to today's research context.

This paper in one of its two part focuses on the interpretation methods used by mufassirin (scholars of interpretation) especially in interpreting and unveiling the words in the al-Quran. Once the interpretation methods had been justified. The paper also will discuss about the Matan and Sanad Criticisms in Evaluating the Hadith.

When we come to the sciences ('Ulum) of the al-Hadith that has long existed we will clearly understand that is the platform for religious scholars to debate the preservation and safeguarding of the originality and authenticity of the Prophet's SAW aHadith. The science is mainly to determine whether to accept or reject the circumstances surrounding the chain of narrators (sanad) and the text of the hadith (matan). The evaluation of a hadith is made based on the sanad and matan criticisms.

The paper will discuss numerous issues pertaining mufassirun methodology used in conducting their Tafsir and methodology used by muhaddithun in authentication of Hadith, the items are as follows: Definition of Tafsir (Interpretation) Method, Definition of Mufassirun, Definition of the Muhaddithun, Comprehensive or In-depth analysis on the Methodology of Mufassirun and Muhaddithun, Tafsir (Interpretation) Methods of the Qur'an, Interpretation Methods in the Past Era, Interpretation Methods in the Modern Era, Standered methodology of Criticism of Hadith Sanad in evaluating Hadith Quality and Benchmarks of the Methodology of Criticism of Hadith Content in determining Hadith Quality.

Copyright @ 2019: This is an open-access article distributed under the terms of the Creative Commons Attribution license which permits unrestricted use, distribution, and reproduction in any medium for non commercial use (NonCommercial, or CC-BY-NC) provided the original author and source are credited. 


\section{DEFINITION OF TERMS}

\section{Definition of Tafsir (Interpretation) Method}

The interpretation or Tafsir method is the combination of two words which are 'method' and 'interpretation'. Method is procedures or set of rules in doing something according to its specific laws and principles [']. Specifically, Qawa'id (method) from the linguistic definition means the origin and foundation built above something. Each method is a base and origin of something that falls under it whether it can be physically seen or not. As an example, a method of a house is also equal to the base of the house [2].

The term of method is an entire law which alongside of it is part of the law or the minor laws [3]. It means that everything should be based on something bigger and smaller so that we can view any circumstances clearer.

Besides, the word interpretation or Tafsir also has gone through a quite long history of its definition thus it has various meanings and understanding. Researchers point out their understanding on the word interpretation according to ancient and modern Islamic scholars.

Etymologically, scholars of Arabic language have a different point of view in deciding the root wood of the word tafsir [4]. Some of them agreed that the word was originated from the verb fasara which was then accumulated to fassara. The word fasara from the linguistic definition has a lot of meaning, which some of them are al-idah (clarifying), al-tabyin (explaining), al-ibanah (enlightening), al-kasyf (unveiling) and al-izhar (determining) [5].

Meanwhile, other scholars of Arabic language suggest that the word tafsir originated from the verb safara [ ${ }^{6}$. According to Al-Khalidy [7], both al-fasara and al-safara are two different words that almost have the same meaning and the pronunciation. Both can be defined as clarifying, unveiling, explaining and enlightening. Nonetheless, the word fasara is usually being used compared to the word safara.

In conclusion, depending to all opinions and definitions stated above, it is clear that the knowledge of interpreting is a technical knowledge and have the same objective to be achieved which is to understand the words in the al-Qur'an through conscience.

\section{Definition of Mufassirun}

An author of a Tafsir is called al-Mufassir, but in plural form they are Mufassirun. In another form Mufassirun are a Qur'anic Interpreters who attempts to provide elucidation, explanation, in-depth interpretation, context or commentary for clear understanding and conviction of Allah's will [8].

\section{Definition of the Muhaddithun}

The term Muhaddith refers to a specialist who intensely knows and narrates hadith, the chains of their narration isnad (Sanad), and the original and famous narrators [?]. Muhaddith is someone who knows hadiths and their chain of transmissions [tariq], names of narrators, and the various wordings [matan] [ ${ }^{10}$. Technically, the term 'Muhaddith can refer either to a transmitter of hadithlor a collector or the compiler of ahadith.

\section{In-depth or Comprehensive analysis on the Methodology of Mufassirun and Muhaddithun}

The paper will be divided into two segments that is two parts, the first segment will discuss the method of the Mufassirun while the second part will discuss about the method of Muhaddithun in analyzing Hadith.

This first segment will be divided into three main segments. Firstly, the discussion on the definition of the interpretation methods; secondly, the discussion on the interpretation methods used by the mufassirin., the first segment is to be discussed on methodology used by mufassirun or interpreters when writing or conducting Tafsir.

\footnotetext{
${ }^{1}$ E. K. Selangor, Kamus Dewan, Dewan Bahasa dan Pustaka, (2013). P. 224.

2 K. U. Al-Sabt, Qawaid al-Tafsir Jam'an wa Dirasah. Beirut: Dar Ibn 'Affan (2001), P.22.

3 lbid, P. 23.

${ }_{4}^{4}$ F. S. Al-Rumiy, Buhuth fi Usul al-Tafsir wa Manahijuhu. Beirut: Maktabah al-Taubat, (1995), P. 2.

${ }^{5}$ M. H. Al-Dhahabiy,. al-Tafsir wa al-Mufassirun. Mesir: Matbacah al-Jamiah, (2001), P. 15.

$6 \mathrm{~J}$. Al-Suyuti, al-Itqan fi 'Ulum al-Quran. Kaherah: Dar al-Husaini, (2008), P. 167.

${ }^{7}$ S. A. Al-Khalidi, Ta'rif al-Darisin Bimanahij al-Mufassirin. Dimasq, Syria: Dar al-Qalam. (2006), P. 305.

8 M. H. Al-Dhahabiy,. al-Tafsir wa al-Mufassirun, Op. Cit, P. 21.

9 M. T. Al-Jawabi, Juhud al-Muhaddisin fi Naqd Matn al-Hadis al-Nabawi al-Syarif. Muassasah Abdil Karim bin Abdillah, Tunis, (1986). P. 23.

$10 \mathrm{lbid}, \mathrm{P} .23$.
} 


\section{Tafsir (Interpretation) Methods of the Qur'an}

The combination of both "method" and 'interpretation' words, 'Interpretation Method' according to al-Sabt [11] and al-Khalidiy ${ }^{[12]}$ is laws as a whole that is capable of unveiling the meaning of the words in the al-Qur'an also determining the procedures of adapting the values from it. Thus, interpretation method is a knowledge that is placing the laws in specific procedures to interpret the words in al-Qur'an. Every process that involves the revealing of the meaning of the words in the al-Qur'an is categorized as interpretation method.

Al-Qur'an interpretation method existed for a long time parallel to the revelation of al-Qur'an to Prophet Muhammad (peace be upon him). Initially, the method was Prophet Muhammad's (peace be upon him) justifications to his Companions (Sahabah) (May Allah be please with them) regarding the words mentioned in the al-Qur'an. The method can be seen when Prophet Muhammad (peace be upon him) made clear of his Companions (Sahabah) (May Allah be please with them) who were quite blurred in understanding the words in the al-Qur'an [13].

The confusion of the fellow Companions (Sahabah) (May Allah be please with them). in understanding the words in the alQur'an and the Prophet Muhammad (peace be upon him) justification regarding the words can be seen clearly from the hadiths. One of them is when the Prophet Muhammad (peace be upon him) interpreted the words in the al-Qur'an with other related words in the alQuran. For instance, he explained regarding the meaning of the phrases 'zulm' mentioned in this words:

"They who believe and do not mix their belief with injustice - those will have security, and they are [rightly] guided." (, 6:82) [14].

He described the phrase 'Zulm' above means superstitious and the establishment of "partners" placed beside Allah SWT and relates it based on other words mentioned in the al-Qur'an:

And (remember) when Luqman said to his son when he was advising him: "O my son! Join not in worship others with Allah. Verily! Joining others in worship with Allah is a great Zulm (wrong) indeed [15].

In general, there are seven methods of al-Qur'an interpretation that are used by the mufassirin in interpreting the alQur'an. These seven methods are substituted into two categories, which are:

\section{Interpretation Methods in the Past Era}

Interpretation methods in the past era are interpretation methods that existed since the legacy of Prophet Muhammad (PBUH) until the 3rd century Hijrah (AH). The interpretation methods that existed at that time also known as interpretation approach. The approaches are tafsir bi al-ma'thur, tafsir bi al-ra'yi and tafsir al-isyariy. The explanations of each interpretation approach are as below;

\section{The Tafsir Bi Al-Ma'thur Method}

Tafsir bi al-ma'thur method is interpreting al-Qur'an with al-Qur'an, al-Sunnah and the utterance of the fellow Companions (Sahabah) (May Allah be please with them) from all aspects in the form of explanation and clarification of Allah SWT's orders from the holy words mentioned in the al-Qur'an $\left.{ }^{16}\right]$. This method is the best way in interpreting the al-Qur'an.

\section{The Tafsir bi al-Ra'y Method}

The Tafsir bi al-ra'y approach is the second approach in al-Qur'an interpretation which means interpreting the al-Qur'an by independent reasoning (ijtihad) once the interpreter knows the Arabic phrase and their language style also steeped the pronunciations and the meaning. Besides that, interpretation scholars must know the reason behind every revelation of words, nasikh and mansukh of every word in the al-Qur'an plus other things that are needed in al-Qur'an interpretation [17].

\section{The Tafsir al-Ishariy Method}

According to al-Zarqaniy [18] and al-Akk [ $\left.{ }^{19}\right](1986: 205)$ this interpretation approach is referred to the attempts took in interpreting the words mentioned in the al-Qur'an without depending on the pronunciations that can be understood clearly and

11 K. U. Al-Sabt, Qawaid al-Tafsir Jam'an wa Dirasah. Op. Cit, P. 30.

12 S. A. Al-Khalidi, Ta'rif al-Darisin Bimanahij al-Mufassirin. Op. Cit, P. 209.

${ }^{13}$ M. K. Al-Qattan, Mabahith fi Ulum al-Quran. Beirut: Muassasah al-Risalah Nasyirun, (2006), P. 20

${ }_{14}$ Qur'an, 6: 82.

${ }^{15}$ Qur'an, 31: 13.

${ }^{16}$ M. H. Al-Dhahabiy, al-Tafsir wa al-Mufassirun, Op. Cit. (2000), P. 112.

17 Ibid, P. 183.

18 M. A. Al-Zarqaniy, Manahil al-'Irfan fi 'Ulum al-Quran. Beirut: Dar al-Kutub al-'Ilmiyyah. (1988). P. 386

${ }^{19}$ Al-Akk, K. A. Usul al-Tafsir wa Qawa'iduhu. Dimasq: Dar al-Nafais, (1986), P. 205 
normally according to the Arabic language, instead it is based on (isharah khafiyyah) implicit signals or hidden signs that can be harmonized and related to the interpretation comprehensibly.

These three interpretation method mentioned above are being used by the mufassirin in their interpretation works. In simple words, interpretation works that give particular focus on other dependable interpretation histories that use hadiths and utterance of the fellow Companions (Sahabah) r.a. and Tabi'in r.a which are guaranteed to be termed accordingly based on the tafsir bi al-ma'thur approach.

\section{Interpretation Methods in the Modern Era}

Interpretation methods in the modern era are interpretation methods existed since the 3rd century Hijrah (AH) until these days. These methods begin to be used right after the books of al-Qur'an interpretation complete until the 30th juz'.

As a whole, there are four methods of interpretation used by the interpreter in interpreting the words mentioned in the alQur'an, which are:

\section{The al-ljmaliy Method (General)}

The al-ljmaliy method is an interpretation method that interprets the words in the al-Qur'an by demonstrating the meanings of the al-Qur'an in simple ways and by using straight forward language. By using this method, the scholars of interpretation complete it with just explaining the whole meaning of the words mentioned in the al-Qur'an [20].

\section{The al-Tahliliy (In-Depth)}

The al-Tahlili method is an interpretation method that explains the contents of the words in the al-Qur'an from the whole aspects according to the arrangement in the al-Qur'an from words to words and surah to surah [ ${ }^{21}$. In addition, in the descriptions, interpreters will include all sorts of problems, stories or any occurrences related to Islamic principles and other perspectives [22].

The specialties of interpretations that are based on this method are firstly, readers will feel like as if they are reading the whole meaning of the words mentioned in the al-Qur'an.

\section{The al-Muqaran Method (Comparison)}

The al-Muqaran method is the interpretation method that interprets the words mentioned in the al-Qur'an by referring to explanation and the differences of the interpretation scholars that are different in the methodology of receiving, analyzing and applying knowledge (manhaj) of the interpretations. The interpretation is limited to one surah or to only one scope such as faith, figh and language and then make comparisons between it. The comparison is not comprehended to the al-Qur'an as a whole but on certain surah or specific topics.

\section{The al-Mawdu'iy Method (Theme)}

The al-Mawdu'iy method is an interpretation method conducted by gathering related words mentioned in the al-Qur'an regarding certain themes and the problems that are being studied. Then, it will be arranged according to the sequence of revelation also evaluate the reasons behind the revelation and relationship between the words, topics and the surahs in the al-Qur'an. Only the, it will be interpreted and analyzed using the interpretation and other knowledge that contains theories that are relevant with the problems studied. This method is conducted to create the boldest concept from the al-Qur'an regarding the problems studied [23]. The second segment is to be discussed on methodology used by muhaddithun or scholars who are knowledgeable of Hadith when writing or analyzing the Hadith.

\section{Objectives of the Sanad and Matan Criticisms}

The aim of criticizing the hadith, either its sanad or matan, is to identify the authenticity of a hadith. The eventual outcome of this criticism is to ascertain if the hadith fulfils the condition on authenticity and enables the differentiation of an acceptable (maqbul) or rejected (mardud) hadith.

\section{Standered methodology of Criticism of Hadith Sanad in evaluating Hadith Quality}

In the sanad criticism, the hadith scholars had evaluated three main issues, such as:

- The piousness and dignity of a narrator would attest to the biasness and competence of a narrator. Narrators who do not fulfil the condition of fairness would have the hadith rejected considering there might be some untruthfulness in the narrations.

20 H. Abuddin Nata. Metodologi Studi Islam. Jakarta: PT Rajagrafindo Persada, (2007), P. 220.

21 Ibid, P. 219. See also N. S. Al-Kiwaniy, Al-Tafsir al-Tahliliy li al-Quran al-Karim tafsir Surah al-Fatihah Namujazan. Amman: Dar alFaruuq, (2011), P. 15.

22 S. A. Al-Khalidi, Ta'rif al-Darisin Bimanahij al-Mufassirin. Op. Cit, P. 31.

${ }_{23}$ F. S. Al-Rumiy, Buhuth fi Usul al-Tafsir wa Manahijuhu, Op. Cit, P. 62. 
- The care shown by the narrator and the prudence in narrating the hadith (dbabt) would attest to the narrator's carefulness, either by him memorizing it or writing in down. Narrators who do not fulfill this condition would have the hadith rejected due to the probability of mistakes. To determine the duty of care, the critics of the hadith would have to evaluate the texts presented by the narrator. Thus, only after the matan criticisms have been made will the status of care be determined.

- To ascertain if the chain of sanad is continuous or otherwise because if the chain has been broken, the hadith is not authenticated and will be rejected since there is a possibility of untruthfulness or mistake when the identity of the narrator in the broken chain is unknown.

\section{Benchmarks of the Methodology of Criticism of Hadith Content in determining Hadith Quality}

Most scholars agree that the research on content should be conducted subsequent to research on sanad, but they disagree on the benchmarks for the validity of content itself. In other words, standard criteria for the validity of hadith content according hadith scholars are varied.

With regard to the benchmarks to examine invalid hadith content, scholars suggest different opinions. Ibn al-Jawzi (d. 597 $\mathrm{AH} / 1210 \mathrm{AD}$ ), for example; argues with a fairly short statement that any hadith contrary to reason or contrary to the principal provisions of the Islam, then it should be known that the hadith is false (mawdhu') [24], because the Prophet Muhammad would never determine any points contrary to common sense, and this applies as well on the provisions of the religion, such as regarding faith and worship.

For more details, the five criteria for standards of hadith Matan (content) criticism will be outlined as follows:

\section{Not contradictive with the instructions of the Qur'an}

Apparently, the critics of hadith content agree that being non-contradictive to the instructions of al-Qur'an should make the first standard in determining the validity of a hadith content. Hence to determine the quality of hadith content, it should be in accordance with the principles of al Qur'an [25].

\section{Not contradictive with more authentic Hadith}

If a narration that is marfu' to the Prophet needs to be rejected, because it is contradictive to a more authentic hadith, the criteria that must be fulfilled comprise: First, there is no possibility to combine them, but when this method is applicable, then there is no need to reject any of them. Furthermore, when there is still a contradiction between the two, then the method employed is to make tarjih. Second, the hadith to be applied as basis for rejecting another hadith should be mutawatir. It is quite logical if the zanniy is rejected, for it is contradictive to the qat'iy ${ }^{[26]}$.

\section{Not contradictive with common sense and authenticated historical facts}

What is meant by common sense here is to be in line with the teachings of the Qur'an and authentic hadith. With reason or common sense scholars have rooms for ijtihad. Therefore, when a narration is found contrary to the senses, practically narration is not valid, and if there is a narration that is at odds with the history, and if in fact the history is supported by strong evidence, then the narration can be confronted with ahad hadith, because ahad hadith is usually relative $\left[{ }^{27}\right]$.

\section{The composition of the wording does not show the characteristics of Prophetic words}

Sometimes a story comes from the Prophet, not in contradiction with the text of the Qur'an or authentic hadith, reason, senses, and history, but its narration does not comprise characteristics of prophetic wordings [ ${ }^{28}$. A narration of such case is not acceptable.

\section{Hadith that have a severe, aggravated or grievous connotation}

Any Hadith that was narrated just to annoy somebody, to irritate or to anger somebody especially with a continuing or trivial annoyance such Hadith or Narration is acceptable because the Prophet himself accused somebody who is doing this act to the people. Furthermore, if the Hadith was narrated or reported with a very harsh and severe act of Ibadah to the people which is beyond the normal sense of mankind such kind of Hadith is rejected.

\section{CONCLUSION}

As a conclusion, based on the whole discussion in this paper research, it is crystal clear that both interpretation methods in the past and modern era. The four interpretation methods; al-tahliliy, al-ijmaliy, al-muqaran and al-mawdu'iy can be used in determining the research design while the al-ma'thur, bi al-ra'yi and al-ishariy approach can be applied in the method of data

${ }^{24}$ A. A. al-Jawzi, Kitab al-Mawduat, vol I (Beirut: Dar al-Fikr, 1403H/1983 M), p. 106.

${ }^{25}$ A. M. Ajjaj. Usul al-Hadis 'Ulumuhu wa Mushtahuhu .Beirut: Dar al-Fikr, 1409 H/1989 M, P. 26.

$26 \mathrm{lbid}, \mathrm{P} .27$.

$27 \mathrm{lbid}$, P. 28.

$28 \mathrm{lbid}$, P. 30 
collection. Based on discussions, obviously there is a close relationship between sanad and matan criticisms when evaluating the hadith. Both these criticisms are essential when criticizing the hadith and in fact, the matan criticism is part of the sanad criticism. It would be incorrect to allege that hadith scholars are inclined or focus more on sanad criticisms when evaluating a hadith, when in fact the allegation portrays the fact that hadith scholars do not ignore matan criticisms when evaluating the hadith.

\section{Bibliography}

1. Abuddin Nata, H. (2007), Metodologi Studi Islam. Jakarta: PT Rajagrafindo Persada.

2. Al-Dhahabiy, M. H. (2000), al-Tafsir wa al-Mufassirun. Kaherah, Mesir: Maktabah Wahbah.

3. Al-Dhahabiy M. H. (2001), al-Tafsir wa al-Mufassirun. Mesir: Matbacah al-Jamiah.

4. Al-Jawabi, M. T. (1986), Juhud al-Muhaddisin fi Naqd Matn al-Hadis al-Nabawi al-Syarif. Muassasah Abdil Karim bin Abdillah, Tunis.

5. Al-Khalidi, S. A. (2006), Ta'rif al-Darisin Bimanahij al-Mufassirin. Dimasq, Syria: Dar al-Qalam.

6. Al-Kiwaniy, N. S. (2011). Al-Tafsir al-Tahliliy li al-Quran al-Karim tafsir Surah al-Fatihah Namujazan. Amman: Dar al-Faruuq.

7. Ajjaj. A. M. (1989), Usul al-Hadis 'Ulumuhu wa Mushtahuhu .Beirut: Dar al-Fikr.

8. Al-Qattan, M. K. (2006), Mabahith fi Ulum al-Quran. Beirut: Muassasah al-Risalah Nasyirun.

9. Al-Rumiy, F. A. S. (t.th), Buhuth fi Usul al-Tafsir wa Manahijuhu. Beirut: Maktabah al-Taubat.

10. Al-Sabt, K. U. (2001), Qawaid al-Tafsir Jam'an wa Dirasah. Beirut: Dar Ibn 'Affan.

11. Al-Suyuti, J. (2008), al-Itgan fi 'Ulum al-Quran. Kaherah: Dar al-Husaini.

12. Al-Zarqaniy, M. A. (1988), Manahil al-'Irfan fi 'Ulum al-Quran. Beirut: Dar al-Kutub al-'IImiyyah.

13. Ibn al-Qayyum, A. A. (1995). al-Maudhuat. Dar al-Kutub al-Ilmiyyah, Beirut.

14. Kamus Dewan-Edisi Ketiga. (2013), Selangor: Dewan Bahasa dan Pustaka. 